\title{
Plant Residues: Short Term Effect on Sulphate, Borate, Zinc and Copper Adsorption by an Acid Oxisol
}

\author{
Ana Cristi Basile Dias, Marcos Antonio Pavan*, Mário Miyazawa and Décio Carlos \\ Zocoler \\ Instituto Agronômico do Paraná - IAPAR; C. P. 481; CEP 86001-970; Londrina - PR - Brazil
}

\begin{abstract}
Laboratory experiments were carried out to examine the effects of plant residues on $\mathrm{Cu}, \mathrm{Zn}, \mathrm{B}$ and $\mathrm{S}$ adsorption by an acidic oxisol. The plant residues were: black oats (Avena strigosa), oil seed radish(Raphanus sativus), velvet beans (Stizolobium cinereum), and pigeon pea (Cajanus cajan) collected at flowering stage. Plant residues increased $\mathrm{Cu}$ and $\mathrm{Zn}$ adsorptions and decreased $\mathrm{B}$ and $\mathrm{S}$ adsorptions. The results indicated that for short term effect plant residues decreased the availabilities of $\mathrm{Cu}$ and $\mathrm{Zn}$ through metal organic complex reactions and increased availabilities of $S$ and B through competition with organic anions by the adsorption sites on soil.
\end{abstract}

Key words: Green manure, cover crop, micronutrient, soil sorption

\section{INTRODUCTION}

Fresh plant residues have water-soluble organic compounds of low molecular weight with high capacity of forming stable complexes with cations and preventing inorganic anion adsorption by acid soils. The water soluble organic compounds contain one or more carboxyl $(\mathrm{COOH})$ and phenolic $(\mathrm{OH})$ functional groups that posses negative charge when fully dissociated. Due to the negative charge associated with these groups, the organic acids can become sorbed to the positive charges on the soil's solid phase or forming complexes with metalic cations in solution.

It is well stablished that pure organic acids prevent inorganic anion adsorption (Appelt et al., 1975; Traina et al., 1986; Evans and Anderson, 1990). These authors concluded that the competition for adsorption sites was the main mechanism for the effect of organic acids on inorganic anion adsorption.Organic acids have also the capacity to form complexes with metals in soil solution (Harter and Naidu, 1995). Based on the stability constants of organic acid-metal complexes (Martell and Smith, 1989) it can be established that organic acids have high affinity for $\mathrm{Zn}^{2+}$ and $\mathrm{Cu}^{2+}$. These studies on metal organic complexes were done with pure organic acid solutions. There has been no direct study comparing the effect of plant residues on the sorption/desorption of cations and anions by soils.

The objective of the present study was to examine the influence of black oats, oil seed radish, velvet beans, and pigeon pea residues on the adsorption of sulphate, borate, zinc and copper by an acidic oxisol.

\section{MATERIAL AND METHODS}

Soil samples taken from the A horizon were airdried, ground, and passed through a $2 \mathrm{~mm}$ sieve. The soil had an original $\mathrm{pH}$ measured in $\mathrm{CaCl}_{2}$

\footnotetext{
* Author for correspondence
} 
slurry with a value of 4.2 ; exchangeable $\mathrm{Ca}, \mathrm{Mg}$, $\mathrm{K}$ and $\mathrm{Al}$ contents of 2.4, 0.92, 0.23 and 0.90 Cmolc $\mathrm{dm}^{-3}$, respectively, and total organic carbon content of $17 \mathrm{~g} \mathrm{~kg}^{-1}$. The clay, silt, and sand contents were 750, 100, and $150 \mathrm{~g} \mathrm{~kg}^{-1}$, respectively. Plant materials were: black oats (Avena strigosa), oil seed radish (Raphanus sativus), velvet beans (Stizolobium cinereum), and pigeon pea (Cajanus cajan). Plant materials were collected at flowering stage, dried at $65^{\circ} \mathrm{C}$ for $48 \mathrm{~h}$, ground to pass $1 \mathrm{~mm}$ sieve, stored in plastic bags, and analyzed (Table 1). Plant materials were added to the soil sample at a rate of $1 \%(\mathrm{w} / \mathrm{w})$.

Table 1 - Chemical composition of plant residues.

\begin{tabular}{lcccc}
\hline \multirow{2}{*}{ Element } & \multicolumn{4}{c}{ Plant residue } \\
\cline { 2 - 5 } & Oats & Radish & Velvet & Pigeon \\
\hline $\mathrm{N}\left(\mathrm{g} \mathrm{kg}^{-1}\right)$ & 29.6 & 29.4 & 25.6 & 29.0 \\
$\mathrm{P}\left(\mathrm{g} \mathrm{kg}^{-1}\right)$ & 4.6 & 5.0 & 1.8 & 2.3 \\
$\mathrm{~K}\left(\mathrm{~g} \mathrm{~kg}^{-1}\right)$ & 35.2 & 30.1 & 44.8 & 12.6 \\
$\mathrm{Ca}\left(\mathrm{g} \mathrm{kg}^{-1}\right)$ & 6.0 & 22.3 & 7.8 & 10.0 \\
$\mathrm{Mg}\left(\mathrm{g} \mathrm{Kg}^{-1}\right)$ & 2.0 & 2.8 & 2.8 & 2.6 \\
$\mathrm{Cu}\left(\mathrm{mg} \mathrm{kg}^{-1}\right)$ & 10.5 & 9.7 & 20.7 & 18.0 \\
$\mathrm{Zn}\left(\mathrm{mg} \mathrm{kg}^{-1}\right)$ & 39.4 & 39.7 & 66.9 & 26.5 \\
$\mathrm{~B}\left(\mathrm{mg} \mathrm{kg}^{-1}\right)$ & 7.7 & 28.4 & 38.8 & 21.1 \\
$\mathrm{Mn}\left(\mathrm{mg} \mathrm{kg}^{-1}\right)$ & 286.4 & 65.8 & 582.3 & 87.2 \\
\hline
\end{tabular}

Zinc, copper, boron, and sulphate solutions were prepared from $\mathrm{ZnSO}_{4} \cdot 7 \mathrm{H}_{2} \mathrm{O}, \mathrm{CuCl}_{2} \quad 2 \mathrm{H}_{2} \mathrm{O}$, $\mathrm{Na}_{2} \mathrm{~B}_{4} \mathrm{O}_{7} \cdot 10 \mathrm{H}_{2} \mathrm{O}$, and $\mathrm{K}_{2} \mathrm{SO}_{4}$, respectively, at the following concentrations: $\mathrm{Zn} \mathrm{4,} \mathrm{8,} \mathrm{16,} \mathrm{32,} \mathrm{and} 64$

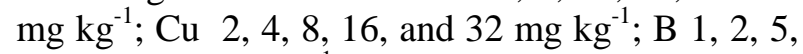

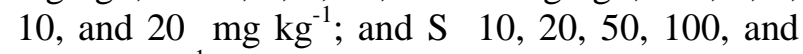
$200 \mathrm{mg} \mathrm{kg}^{-1}$. Sorptions of $\mathrm{Zn}, \mathrm{Cu}, \mathrm{B}$ and $\mathrm{S}$ in the presence and absence of plant residues were measured by shaking duplicates $5 \mathrm{~g}$ samples of soil with $5 \mathrm{ml}$ solutions containing appropriate amounts of each element, in $50 \mathrm{ml}$ centrifuge tubes. Amended soil samples were incubated for 5 d. Then, the extractant solutions were added, shaked, centrifuged at $2500 \mathrm{rpm}$ for 10 minutes, filtered, and the concentrations of $\mathrm{Zn}, \mathrm{Cu}, \mathrm{B}$, and $\mathrm{S}$ were determined by inductively coupled plasma (ICP) spectroscopy. The extractant solutions were DTPA for $\mathrm{Zn}$ and $\mathrm{Cu}$ (Raij et al., 1996), $0.05 \mathrm{~mol}$ $\mathrm{L}^{-1} \mathrm{HCl}$ for B (Correa et al., 1985) and $0.01 \mathrm{~mol} \mathrm{~L}^{-}$ ${ }^{1} \mathrm{Ca}\left(\mathrm{H}_{2} \mathrm{PO}_{4}\right)_{2} .2 \mathrm{H}_{2} \mathrm{O}$ for $\mathrm{S}$ (Raij et al., 1996). Sorbed $\mathrm{Zn}, \mathrm{Cu}, \mathrm{B}$ and $\mathrm{S}$ were calculated as the difference between the amount added and the amount remaining in the extractant solution after shaking. All treatments were performed in triplicate, and standard error of the treatment means were calculated.

\section{RESULTS AND DICUSSION}

At least for short term experiment, all plant residues increased $\mathrm{Cu}^{2+}$ and $\mathrm{Zn}^{2+}$ adsorptions by the soil (Fig. 1 and 2). Due to the negative charges associated with carboxyl and phenolic functional groups of the organic compounds, $\mathrm{Cu}^{2+}$ and $\mathrm{Zn}^{2+}$ were readly sorbed on the organic phase. The acidic function groups of the organic compounds presented acidic properties in which the $\mathrm{H}^{+}$ions can be replaced under certain circunstances by metalic ions, such as $\mathrm{Cu}^{2+}$ and $\mathrm{Zn}^{2+}$ forming coordinated bounds.

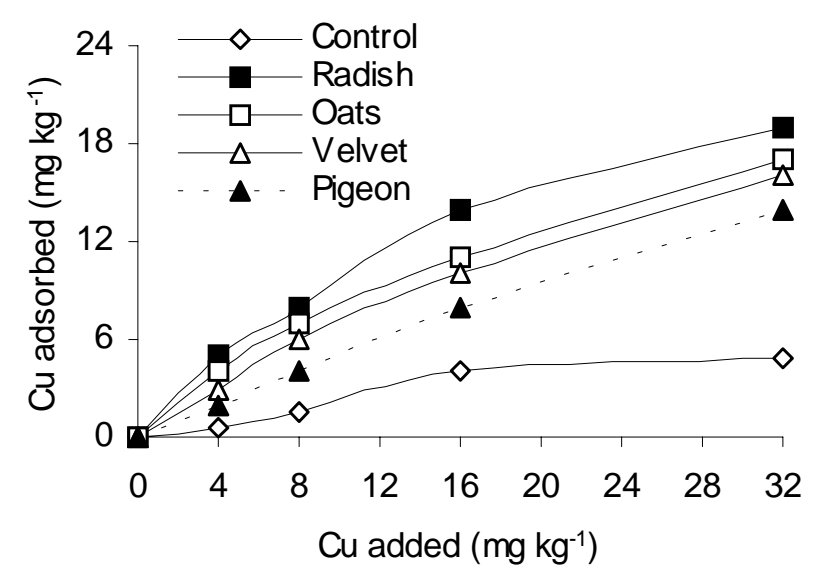

Figure 1 - Effect of plant residue on $\mathrm{Cu}$ sorption. 
The greather adsorption of $\mathrm{Cu}^{2+}$ in relation to $\mathrm{Zn}^{2+}$ was probably due to higher stability constant of the $\mathrm{Cu}^{2+}$-organic forms (Martell and Smith, 1989).

The degree of metal sorption, however, depended on the particular plant species. The effect of plant residue on $\mathrm{Cu}^{2+}$ and $\mathrm{Zn}^{2+}$ sorptions followed the order: oil seed radish $>$ black oats $>$ velvet beans $>$ pigeon pea. These results indicated that for short term effect plant residues could decrease the availability of $\mathrm{Cu}^{2+}$ and $\mathrm{Zn}^{2+}$ in soil through metal organic complexes due to the high stability constants of $\mathrm{Cu}^{2+}$ and $\mathrm{Zn}^{2+}$ with organic anions (Lide, 1992). Thus in marginal cases it might be possible to alleviate $\mathrm{Cu}$ and $\mathrm{Zn}$ toxicities by proper use of plant residues.

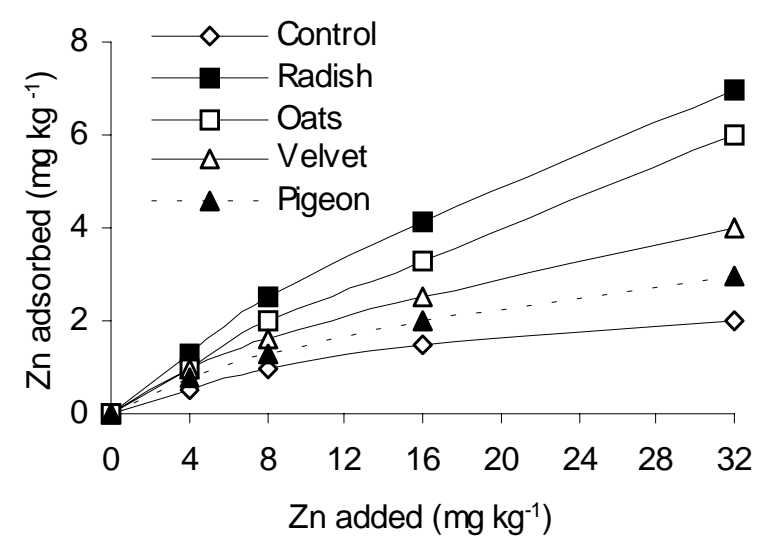

Figure 2 - Effect of plant residue on Zn sorption.

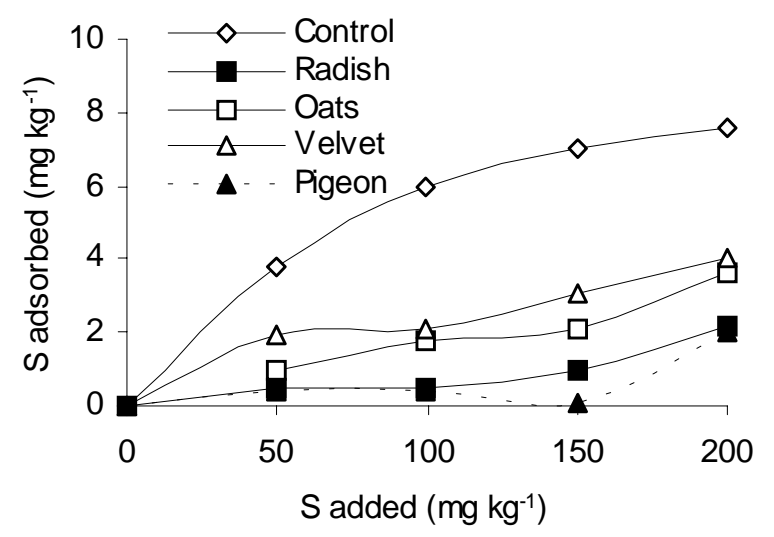

Figure 3 - Effect of plant residue on S sorption.

The higher adsorption capacity of oil seed radish and black oats by $\mathrm{Cu}^{2+}$ and $\mathrm{Zn}^{2+}$ was probably due to their higher amounts of acidic functional groups (Cassiolato et al., 2001) and to their higher proportion of forming stable complexes with cations (Franchini et al., 2001). It was unlikely that organic residues formed precipitates with $\mathrm{Cu}^{2+}$ and $\mathrm{Zn}^{2+}$ in soil.

On the other hand the presence of plant residue decreased the adsorption of S and B by soil (Fig. 3 and 4). The decrease in adsorption was higher for $\mathrm{B}$ than for $\mathrm{S}$, probably due to weaker competition of borates than sulphates with organic anions by the adsorption sites. Various reasons have been proposed for the decrease in the adsorption of anions in the presence of organics.

Organic anions released from the plant materials competed with inorganic anions such as borates and sulphates for the positive adsorption sites on soil and thereby decreasing $\mathrm{S}$ and $\mathrm{B}$ adsorptions. Typically plant residues contain many organic acids with low molecular weight varying in chain length (Franchini et al., 2001) which can carry negative charges, thereby allowing the competition with inorganic anions with soil matrix. Studies with inorganic and organic anions have shown that sorption trend was phosphate $>$ oxalate $>$ malate $>$ sulphate $>$ acetate (Jones and Brassington, 1998). It was probably that these anions share similar sorption sites on soil and were all capable of preventing the sorptions of added $\mathrm{S}$ and $\mathrm{B}$. Thus plant residues could improve $\mathrm{S}$ and $\mathrm{B}$ availabilities by decreasing their sorptions in soil and consequently ameliorating S and B nutritions.

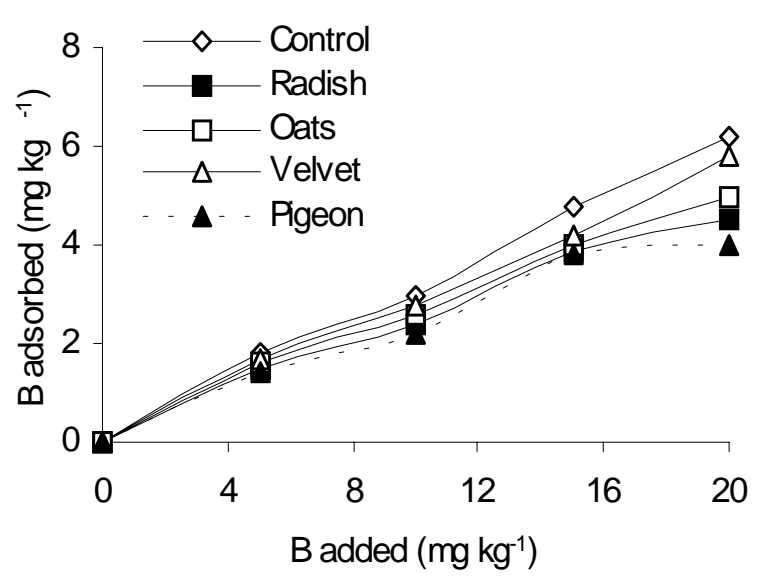

Figure 4 - Effect of plant residue on B sorption. 


\section{CONCLUSIONS}

Plant residues decreased the availabilities of $\mathrm{Cu}^{2+}$ and $\mathrm{Zn}^{2+}$ through metal organic complex reactions and increased the availabilities of $\mathrm{S}$ and $\mathrm{B}$ through competition with organic anions by the soil adsorption sites.

\section{RESUMO}

Resíduos vegetais frescos possuem compostos orgânicos hidrossolúveis de baixo peso molecular com alta capacidade de complexação com cátions e de competição na adsorção de ânions em solos ácidos. Foram conduzidos experimentos de laboratório para avaliar os efeitos de resíduos de aveia preta (Avena strigosa), nabo forrageiro (Raphanus sativus), mucuna anã (Stizolobium cinereum) e guandu (Cajanus cajan), coletados em pleno florescimento, na adsorção de $\mathrm{Cu}, \mathrm{Zn}, \mathrm{B}$ e $\mathrm{S}$ por um latossolo ácido. Os resíduos vegetais aumentaram a adsorção de $\mathrm{Cu}$ e $\mathrm{Zn}$ e diminuíram as de $\mathrm{B}$ e $\mathrm{S}$. Os resultados indicaram que as transformações rápidas dos compostos orgânicos dos resíduos vegetais diminuem a disponibilidade de $\mathrm{Cu}$ e $\mathrm{Zn}$ através de reações de complexação organo-metálica e aumentam as de $\mathrm{S}$ e B através de competição com ânions orgânicos pelos sítios de adsorção do solo.

\section{ACKNOWLEDGEMENT}

Ana Cristi Basile Dias thanks CNPq for the award of a scholarship.

\section{REFERENCES}

Appelt, H.; Coleman, N. T. and Pratt, P. F. (1975), Interactions between organic compounds, minerals, and ions in volcanic ash derived soils. II. Effects of organic compounds on the adsorption of phosphate. Soil Sci. Soc. Am. Proc., 39, 628-630.

Cassiolato, M. E.; Miyazawa, M.; Meda, A. R. and Pavan, M. A. (2001), A laboratory method to estimate the efficiency of plant extract to neutralize soil acidity. Braz. Arch. Biol. Tech. [Accepted for publication on March, 9, 01].

Correa, A. E.; Pavan, M. A. and Miyazawa, M. (1985), Aplicação de boro no solo e respostas do cafeeiro. Pesq. Agrop. Bras., 20, 177-181.
Evans, A. and Anderson, T. J. (1990), Aliphatic acids: influence on sulphate mobility in a forested acid soil. Soil Sci. Soc. Am. J., 54, 1136-1139.

Franchini, J. C.; Gonzalez-Vila, F. J.; Cabrera, F.; Miyazawa, M. and Pavan, M. A. (2001), Rapid transformations of plant water-soluble organic compounds in relation to cation mobilization in an acid Oxisol. Pl. Soil, 231, 55-63.

Harter, R. D. and Naidu, R. (1995), Role of metalorganic complexation in metal sorption by soils. $A d v$. Agr., 5, 219-263.

Jones, D. L. and Brassington, D. S. (1998), Sorption of organic acids in acid soils and its implications in the rhizosphere. Eur. J. Soil Sci., 49, 447-455.

Lide, D. R. (1992), CRC Handbook of chemistry and physics. $27^{\text {nd }}$ edition. Boca Raton. pp. 8-43.

Martell, A. E. and Smith, R. (1989), Critical stability constants. New York : Plenum Press. 6 v. 349 pp.

Raij, B. Van; Cantarela, H.; Quaggio, J. A. and Furlani, A. M. C. (1996), Recomendações de adubação e calagem para o estado de São Paulo, 2. ed. Campinas : Instituto Agronômico and Fundação (IAC). (Boletim Técnico; 100). 285 pp.

Traina, S. J.; Sposito, G.; Hesterberg, D. and Kafkafi, U. (1986), Effects of $\mathrm{pH}$ and organic acids on orthophosphate solubility in an acidic montmorillomitic soil. Soil Sci. Soc. Am. J., 50, 45-52.

Received: April 12, 2001; Revised: August 13, 2001; Accepted: February 04, 2002. 